\title{
Determination of Chromium in the Tannery wastewater, Korangi, Karachi
}

\author{
Omm-e-Hany ${ }^{1}$, Asia Neelam²*, Aamir Alamgir ${ }^{3}$ and Humaira Kanwal ${ }^{4}$ \\ Institute of Environmental Studies, Karachi, Pakistan
}

Submission: October 27, 2018; Published: December 11, 2018

*Corresponding author: Asia Nelam, Institute of Environmental Studies, Karachi, Pakistan

Abstract

Chromium is an important metal used in vast range of industrial units. The major contributor remains tannery industry. The aim of the present study was to determine wastewater quality of tanneries effluent of Korangi Site with the estimation of chromium pollution levels. Analysis of selected parameters (TSS, TDS, pH, BOD, COD and chromium) have shown results to be within acceptable limits (in April, May and June) except for chromium, having exceeded concentrations of $10.26 \mathrm{ppm}$ and $13.05 \mathrm{ppm}$ in the month of May and June respectively. The analysis result emphasized the use efficient tanning processes and implementation of best industrial practices, recycling and recovery of chromium. It is recommended to use efficient treatment plants having feasible physico-chemical and/ or biological treatment options, and implementation of polluters pay principle for individual sense of responsibility of industrial units against deuteriation of environment and carcinogenic effect of chromium on human health. The possible reasons for the absence of chromium in the month of April has been mentioned. However, the actual reasons remain unclear due to lack of additional information and has identified an important area for further research to have answers.

Keywords: Carcinogenic; Wastewater; Chromium; Tanning Process

\section{Introduction}

In Industries toxic waste are released from different chemical processes into the environment [1]. Chromium (Cr) is an important metal used in a wide range of industrial processes, the prominent industrial sectors are electroplating, metal finishing industries, leather tanning, chromate preparation [2], oxidative dyeing unit, textile dyeing, and water-cooling towers [3] and is therefore considered as a major environmental toxin [4]. Among all the industrial secotrs, effluent released from tanneries is categorized as major contributor of chromium pollutant [5]. Out of the total leather exports of Pakistan, Korangi alone covers one third of it. A number of industrial units are clustered in Korangi that are making this significant contribution in Leather Exports. Almost 170 tanneries are reported in Korangi besides the unofficial number that exceeds well above the stated figure [6]. Therefore, Korangi tanneries have been well known and marked for their adverse effects on the environment and level of pollution particular in temrs of chromium. Usually sulphate salts of chromium (III) are applied as tanning agent, almost $90 \%$ of the tanning industry uses basic chromium sulfate. Out of the total chromium applied in the tanning process, $60-70 \%$ is actually consumed, whereas rest of the $30-40 \%$ remains unconsumed. It is this unconsumed chromium that goes away with the industrial effluent [7]. Overall tanning process degrades the environment by polluting surface waters, air, land, groundwater. In particular, tanning causes rapid decline in chemical, physical and biological characteristics of surface water thereby producing obnoxious odor by the degradation of hair and skin material. Chromium with other pollutants (sulphides and ammonia) causes toxicity, while algal growth is accelerated (due to nitrogen-based compounds), suffocating other life forms due to depletion of dissolved oxygen and sunlight.

There are two predominant species (with different oxidation states) of chromium in the environment, $\mathrm{Cr}$ (III) and $\mathrm{Cr}$ (VI). Both these species present different biological, geochemical and toxicological properties [8]. Cr (III) is considered of biological importance for mammals within very limited range, helping in the regulation of metabolic processes of glucose $[8,9]$ and proteins [10]. Chromium (III) is comparatively less mobile [11] whereas chromium (VI) is found to be more soluble in water. Toxicological studies revealed potential effects of chromium (VI) on human health. It is highly toxic, mutagenic and carcinogenic [12] for the mammals. In General, toxic effects of chromium are linked with long-term low-level exposures in our environment. However, chromium (VI) has shown toxicity for both acute and chronic exposures [13]. The maximum acceptable concentration of $\mathrm{Cr}$ (VI) discharged into inland surface water is $0.1 \mathrm{mg} / \mathrm{L}$ [14] whereas in drinking water, it is $0.05 \mathrm{mg} / \mathrm{L}[12,14,15]$. Its exposure is associated with many chronic diseases; respiratory illnesses, ulcers and perforation of the nasal septum as well as increased lung and nasal cancer $[4,16]$, skin irritation diseases,dermatitis [10], eczema, conjunctivitis, liver and kidney damage [17-19]. It is the chromium (III) of tanning agent that is transformed into chromium (VI) thorught oxidation, becoming the source of chromium (VI) pollution and associated health hazards as indicated in former section. 
The objective of our study is to determine the wastewater quality of Korangi Nala and to assess the concentration of chromium in the tanneries industrial effluent. The concentration of chromium will not only determine the level of pollution but will also indicate the level of efficiency of tanning processes in tanneries unit of Korangi.

\section{Material and Method}

Both the inlet and the outlet are the location for the sample from the combine tannery waste flow. Duplicate sample were taken from the inlet of Korangi Nala by using a PET plastic bottles, (waste water discharge into the main river flow down into the Arabian Sea) at afternoon in the month of April, May and June that was the average production period of leather in Karachi. For the determination of parameter, samples were stored in the fridge until the time for the sample to be analyzed. All the sample were pretreated to remove floated materials. Chromium was determined by using the ion-exchange chromatography, by the separation of different cations and anions, it becomes easier for the determination of chromium (VI) species. Induced Couple Plasma (ICP) Model no. Plasma 2000 was used for the analysis of chromium. In the sample it was determined with reference to the standard calibration curve via Inductively Coupled Plasma Model number 2000. Chromium analysis results were determined with reference to calibration curves which were developed by the use of Standard solution preparations of chromium. Other parameters tested for wastewater were Biological oxygen demand (BOD), Chemical oxygen demand (COD), Total dissolved solids (TDS), Total suspended solids (TSS), Total solids (TS) and pH [20].

Table 1: Comprehensive Table of the Analysis.

\section{Result and Discussion}

According to the analysis results presented in Table 1, wastewater parameters i.e., TSS, TDS, BOD, COD, $\mathrm{pH}$ all are within the SEQs limits. However, varied outcome of chromium is obtained. The chromium concentration is showing exceeded values of 10.26, $13.05 \mathrm{ppm}$ for the month of May and June respectively. In contrast to it, no chromium was found for the month of April. The presence of high levels of chromium (i.e, above than SEQs limit of $1 \mathrm{mg} / \mathrm{L}$ ) for the month of May and June not only determines heavy pollution load exerted by chromium butalso indicates the probable inefficient tanning processes in practice. However, it is to be noted that the cause of exceeding results may also be contributed due to inefficient operational conditions of combine effluent treatment plant. On the other hand, absence of chromium in the month of April can have multiple reason. One possible reason can be related to $\mathrm{pH}$ of the wastewater. Since chromium states are $\mathrm{pH}$ dependent therefore, both species are interchangeable based on wastewater characteristics and pH. Therefore, determination of levels of chromium species (III) and (VI) from the tannery industries remains difficult. In basic medium reduction in chromium (VI) concentration from the tannery wastewater can be achieved. Therefore, the basic $\mathrm{pH}$ of the month of April sample, might have idcuced the chromium VI) transformation and it might have settled down in the bottom as oxides. becoming part of sludge. Other possibility could be the consumption of chromium in wastewater due to availability of high organic waste (especially proteins), the reaction is very rapid forming protein-chrome precipitates that are added into the sludge of the wastewater.

\begin{tabular}{|c|c|c|c|c|c|}
\hline \multirow{2}{*}{ S NO } & \multirow{2}{*}{ Parameters } & \multicolumn{2}{|c|}{ Analysis Results (mg/L or otherwise defined) } & \multirow{2}{*}{ SEQs Limit (mg/L) } \\
\cline { 3 - 6 } & & April & May & 6.38 & 200 \\
\hline 1 & TSS & 20.01 & 19.36 & 21.42 & 3500 \\
\hline 2 & TDS & 5.394 & 7.92 & 27.8 & ND \\
\hline 3 & TS & 25.404 & 27.28 & 5.34 & $6-9$ \\
\hline 4 & pH & 10.1 & 4.83 & 33.24 & 80 \\
\hline 5 & BOD & 5.374 & 63.08 & 51.651 & 150 \\
\hline 6 & COD & 12.39 & $10.26 \mathrm{ppm}$ & $13.05 \mathrm{ppm}$ & $1 *$ \\
\hline 7 & Chromium & $0.0 \mathrm{ppm}$ & & & 1 \\
\hline
\end{tabular}

The high concentration of chromium in other two months (May and June) can also be associated with $\mathrm{pH}$ values. The $\mathrm{pH}$ values for the month of May and June indicate acidic conditions of wastewater. It has been reported that most mobile forms of chromium (VI) prevailing in acidic conditions are $\mathrm{HCrO}_{4}{ }^{1-}$ and $\mathrm{Cr}_{2} \mathrm{O}^{2-}$ ions [4]. However, in slightly acidic condition ( $\mathrm{pH}$ range of above 5.5) the level of chromium (III) species are reduced in wastewater effluent. Therefore, higher concentration of chromium in these months indicates potential presence of hazardous chromium (VI) species which is predominately formed due to chromium (III) species oxidation.

It is evident that tanning processes of Korangi industrial area are not meeting the standards. Besides the efficient use of chromium (III) is also required in order to reduce the chromium
(VI) production in wastewater of tanneries units. There are varied practices and approaches that can be adopted at different levels to make tanning processes efficient. The inefficient use of $\mathrm{Cr}$ (III) and its release into the environment has to be reconsidered through adopting an appropriate recycling and recovery system. It is reported, that recovery of $\mathrm{Cr}$ from spent tanning and retanning baths provides a significant economic advantage in terms of both its reuse and simplification of the wastewater treatment [12]. The first approach of recycling i.e., is direct reuse of the chromium liquor after filtering and reconstitution useful to reduce the chromium concentration in wastewater and it appears to be least complex in terms of physical/ chemical operations. The second approach of chromium recovery form waste liquor is, precipitation/dissolution. It has appeared that virtually all of 
the chromium that is precipitated may be recovered for reuse in tanning process. It is experimentally proved that $70-80 \%$ chromium is consumed in hides and skin during tanning process and the remaining $20-30 \%$ becomes part of process effluent, an important resource is drained out and ultimately waste. To utilize this quantity chromium recovery plants can be installed [21]. Typically, chromium (III) is recoverd from the industrial effluent in the form of chromium hydroxide by raising the $\mathrm{pH}$ of wastewater with the addition of chemicals and/or coagulants like lime and iron compounds. Recovery of chromium (III) from this method is said to be $99.5 \%$ [4]. The recovered chromium can be reused after reconstituting according to process requirements. It is further reported that the process efficiency in terms of color, softness, shine, texture, quality surface and smoothness of the leather is not affected due to the use of recovered chromium [21]. In terms of cost effectiveness, the recovered chromium remains cost effective as it accounts for $1 / 3$ rd of the cost of new chromium [6] provided that wastewater contains higher amount of chromium for recovery. Thus, direct recycle (with reconstitution) is the more efficient and cost-effective approach [22] before steping towards recovery options.

Besdies recycling and recovery options, the amount of chromium (VI) in wastewater can be reduced by inhibiting the transformation of remaining chromium (III) to chromium (VI). Oxidation of chromium (III) is a critical process where the non-hazardous species is transformed into hazardous species chromium (VI). Fortunately, the only known oxidation agent of chromium (III) that is naturally present are manganeseoxides. The conversion of $\mathrm{Cr}$ (III) is dependent on $\mathrm{Cr}$ (III)- $\mathrm{MnO}_{2}$ complex and the reaction that inhibit or controls the formation of this complex may reduce the chances of $\mathrm{Cr}$ (III) transformation. One of the options available to inhibit Cr (III) oxidation or compex formation is by the retention of chromium (III) through sorbent material present in soils or waters that are non-redox reactive such as permanently charged aluminosilicate clay minerals [8]. However, as the heavy metal ions are shifted from liquid phase therefore, sorption reactions may regulate the risk of these metal ions in other compartments of environment (solid or liquid) Thus, fate of heavy metal ions in such treatment options should be clearly known before its application at commercial scale.

Another option for eliminating the chromium (VI) concentration in wastewater is to reduce this species into chromium (III) i.e., non-hazardous form. Biotransformation or biodegradation is one of the feasible option available in this regard. Microorganisms (aerobic and anaerobic) bearing the potential of chromium (VI) conversion to chromium (III) can play vital part in the detoxification of wastewater from chromium (VI) species. Studies on Pseudomonas species has reported enzymes named as chromium reductase that can reduce chromium (VI) to chromium (III) [23]. Besides, a number of microorganisms (bacteria and fungi) have been reported to remove chromium from tannery waste, some of these include, Bacillus sp., Pseudomonas sp., Desulfovibrio sp, Escherichia coli., Microbacterium sp, Enterobacter sp., and in group of fungi Nostoc, cyanobacteria and Aspergillus spp [23].
Microorganisms are capable to reduce chromium (VI) are recognized as chromium reducing bacteria (CRB).

The waste water treatment plants (WWTPs) remains the last necessary options to ultimately discharge polluted water within the acceptable legislative limits of hazardous substance. For industrial sectors or sites, it is suggested to have a combine effluent treatment plant to finally process all hazardous waste. However, in case of Korangi industrial site, lack of sufficient individual treatment facilities as well as clear denial of certain tanners in Korangi to contribute a significant protion in the operational and maintenance cost of the combine effluent treatment plants (CETPs), has also lead to worsen the pollution situation. Review of past events and negociation between government and tanneires, indicated constrains for these units to unanimously agree upon a single joint remediation pollution prevention option [24]. Therefore, as a minimum, all tanneries can comply with their legislative obligations by installing individual WWTPs [25].

\section{Conclusion and Recommendations}

The study validates the waste water quality of Korangi nala and situation of receiving water bodies deteoiration due to chromium pollution. High chromium levels clearly indicate inefficient tannig process are in practice by Koranig tanneries units. It also realtes the potential health profile of workers in particular and public in general who are getting expose to higher concentration of chromium; indicating speard of various environmental health issues. In order to reduce chromium based impacts on environment and human health, there is dire need to update tanning processes to improve its efficiency. Pollution load could be redcued by in-house improvements in operational and maintenance methods and activities by individual units. Besides process improvements, successful options of reuse and recovery of chromium in tanning industries if not, must be adopted. Besdies being cost effective with no compromise on the process efficieny and product quality these approaches will also reduce environmental pollutin load and impact on human health. Therefore, tanneries unit should be encouraged to carry out reuse and recovery options.

Nations word wide have achieved enforcement of regulation through various strategies, one of the successful strategies is Polluters Pay Principal (PPP). However, the failure in use of such tools over the last 25 years in Pakistan has led to several challenges and consequences for environmental management and human health. In general (with few exceptions), the consultations between the government agencies and tannery industry remains to have overall no useful output. As the behavior remains to establish committees that work slowly to have concensus among all the stakeholders, ultimately ending up with no mutual agreement i.e., no workable and useful way forward. This attitude remains key hurdle in managing crucial issues relating to chromium pollution in our city. In the situation of disagreement between tanneries units for cooperation in regard to the CETPs, adoption of the PPP remains as a central strategy for protection against environmental degradation and impact on human health. The active implementation of PPP by the concerned regulatory 
authority (in this case SEPA) seems to have great potential to make industrial units realize the full extent of its obligation and liability with respect to pollution mitigation. A detailed route cause analysis needs to be performed in order to obtain additional information to identify the actual reason behind no chromium in the month of April. It may open doors to a more feasible option to have no chromium in tanneries waste.

\section{References}

1. TT Shen (1990) Industrial pollution prevention ( $2^{\text {nd }}$ Edn.) p. 40.

2. Parveen R, Mohammad Ashfaq (2013) Estimation of chromium in effluents from tanneries of Korangi industrial area. Pakistan Journal of Chemistry 3(1): 29-33.

3. Kortenkamp A, Stephen P Faux (1996) A role for molecular oxygen in the formation of DNA damage during the reduction of the carcinogen chromium (VI) by glutathione. Archives of Biochemistry and Biophysics, 329(2): 199-207.

4. Parveen R, Mohammad Ashfaq (2013) Estimation of Chromium in Effluents from Tanneries of Korangi Industrial Area. Pak J Chem 3(1): 29-33.

5. Altaf MM, F Masood, A Malik (2008) Impact of long-term application of treated tannery effluents on the emergence of resistance traits in Rhizobium sp. isolated from Trifolium alexandrinum. Turkish Journal of Biology 32(1): 1-8.

6. Aslam SM (2000) Social and economic cost of tanneries, Industry and Economy.

7. Sarker BC, B Basak, MS Islam (2013) Chromium effects of tannery waste water and appraisal of toxicity strength reduction and alternative treatment. International Journal of Agronomy and Agricultural Research, 3(11): 23-35.

8. Fendorf SE (1994) Mechanisms of chromium (III) sorption on silica. 1. Chromium (III) surface structure derived by extended x-ray absorption fine structure spectroscopy. Environmental science \& technology 28(2): 284-289.

9. B Basak, M Sajedul, Biddut Chandra Sarker , Bristy Basak, Md Sajedul Islam (2013) Chromium effects of tannery waste water and appraisal of toxicity strength reduction and alternative treatment, International Journal of Agronomy and Agricultural Research (IJAAR). International Journal of Agronomy and Agricultural Research (IJAAR) 3(11): 23-35.

10. Michael Sperling, SX, Bernhard Welz (1992) Determination of chromium (III) and chromium (VI) in water using flow injection online preconcentration with selective adsorption on activated alumina and flame atomic absorption spectrometric detection. Analytical Chemistry 64(24): 3101-3108.

11. Arachchi R, G Fernando (2011) Reduction of Chromium Levels in Waste Water and Industrial Sludge using Low Cost Stabilization Technology.

12. Saranraj P, D Sujitha (2013) Microbial bioremediation of chromium in tannery effluent: a review. Int J Microbiol Res 4: 305-320.

13. (1998) SAIC, PM/Toxics Integration: Addressing Co-Control Benefits.

14. (2016) SEPA, Sindh Environmental Quality Standards. January, Sindh Environment Protection Agency.

15. (1990) EPA, Environmental Pollution Control Alternatives E.P. Agency, USA.

16. NIOSH (2013) Criteria for a Recommended Standard: Occupational Exposure to Hexavalent Chromium, N.I.f.O.S.a.H. (NIOSH), NIOSH Publication No. 2013-128.

17. (1998) US-EPA, Toxicological Review of Hexavalent Chromium (CAS No. 18540-29-9). Washington DC, USA.

18. California, California Safe Drinking Water and Toxic Enforcement Act 1986, USA.

19. Raji C, T Anirudhan (1998) Batch Cr (VI) removal by polyacrylamidegrafted sawdust: kinetics and thermodynamics. Water Research 32(12): 3772-3780.

20. APHA (1989) Standard methods for the examination of water and wastewater. 1989: Washington, DC, USA.

21. CPI (2000) Chrome Recovery, Recycling and Reuse of Dusted Salt.

22. Gu JD, K Cheung (2001) Phenotypic expression of Vogesella indigofera upon exposure to hexavalent chromium, $\mathrm{Cr}^{6}+$. 17(5): 475-480.

23. Camargo F, Bento FM, Okeke BC, Frankenberger WT (2003) Chromate reduction by chromium-resistant bacteria isolated from soils contaminated with dichromate. Journal of Environmental Quality 32(4): 1228-1233.

24. Luken RA (2009) Equivocating on the polluter-pays principle: The consequences for Pakistan. Journal of environmental management 90(11): 3479-3484.

25. Voice TC (1998) Evaluation of chromium recovery opportunities in a leather tannery. Hazardous waste and hazardous materials 5(4): 343352.

\section{Your next submission with Juniper Publishers} will reach you the below assets

- Quality Editorial service

- Swift Peer Review

- Reprints availability

- E-prints Service

- Manuscript Podcast for convenient understanding

- Global attainment for your research

- Manuscript accessibility in different formats

( Pdf, E-pub, Full Text, Audio)

- Unceasing customer service

Track the below URL for one-step submission https://juniperpublishers.com/online-submission.php 